\title{
LAW NUMBER 19 YEAR 2008 ON THE CONCERNING STATE SHARIA BONDS (SBSN/SUKUK) LEX SPECIALIST OF LAW NO. 1 OF 2004 ON STATE TREASURY MAQASHID AL-SHARIAH PERSPECTIVE
}

\author{
Fathurrahman $^{1}$ Muslimin H Kara ${ }^{2}$ M. Wahyuddin Abdullah ${ }^{3}$ Wahid Haddade $^{4}$ \\ Correspondent Email : ftrahman51@gmail.com \\ STAIN Majene, West Sulawesi
}

\begin{abstract}
This study examines in depth the dual function of the State Sharia Bonds in Law Number 19 Year 2008. This syariah economic product is interesting to study because it contains aspects of benefit as in maqashid as-shari'ah. The research is intended to review the business side and speculation of sharia products to prevent people from fraud and events containing garar. By using a qualitative analysis using the sharia economic approach, this research found that the government's superior products in the State Sharia Bonds are protected from fraud and garar.

Law No. 19 of 2008 concerning the State Shariah Bonds is lex of Law No. 1 of 2004 on the state Treasury and use state assets. SBSN is a product of two dimensions, namely SBSN as an investment product, and SBSN as a country and project financing for the Government and the public interest in containing maqashid as-Shari'ah in order to keep religion, soul, mind, wealth, and honor.
\end{abstract}

\section{Keywords:}

SBSN, Maqashid as-Shariah, Sukuk; Garar

\begin{abstract}
Abstrak
Penelitian ini mengkaji secara mendalam fungsi ganda dari Obligasi Syariah Negara dalam Undang-Undang Nomor 19 Tahun 2008. Produk ekonomi syariah ini menarik untuk diteliti karena mengandung aspek-aspek kemaslahatan sebagaimana dalam maqashid as-syari'ah. Penelitian
\end{abstract}

1 Republic of Indonesia, Law Number 19 Year 2008 concerning State Sharia Bonds

2 Republic of Indonesia, Government Regulation No. 56 of 2008, concerning the Project Financing Through State Shariah Securities Issuance

3 Ministry of Finance, Tanya Books Shariah Securities, second edition, 2010, p. 16

4 Ministry of Finance, Tanya Books Shariah Securities, Second Edition, 2010, p. 16 
dimaksudkan untuk mengulas sisi bisnis dan spekulasi produk syariah untuk menghindarkan masyarakat dari penipuan dan perjuadian yang mengandung garar. Dengan menggunakan analisis kualitatif dengn pendekatan ekonomi syariah, maka penelitian ini menemukan bahwa produk unggulan pemerintah dalam Obligasi Syariah Negara, terlindung dari penipuan dan garar.

Undang-Undang Nomor 19 Tahun 2008 tentang Obligasi Syariah Negara adalah Undang-Undang Nomor 1 Tahun 2004 tentang Perbendaharaan Negara dan menggunakan aset negara. SBSN adalah produk dua dimensi, yaitu SBSN sebagai produk investasi, dan SBSN sebagai pembiayaan proyek negara untuk Pemerintah dan kepentingan publik dalam mengandung maqashid as-syari'ah untuk menjaga agama, jiwa, pikiran, kekayaan, dan kehormatan.

Kata Kunci:

SBSN;Maqashid as-Shari'ah; Sukuk; Garar

\section{A. INTRODUCTION}

Law Number 19 the Year 2008 concerning the State Sharia Bonds (SBSN / Sukuk) is a specific law governing the Sukuk in Indonesia, of this Act is also a trigger of more popular Islamic bonds in Indonesia. SBSN Act states "that national development policies and strategies to achieve a fair society, prosperous, and prosperity and to restore economic sectors, need to be accompanied by efforts optimal management of state finances through increased efficiency in the management of state property and sources of financing of the state budget ". ${ }^{5}$ Birth of Act No. 19 of 2008 was also the basis for the state budget to finance Indonesia, where the Indonesian government to cover the budget shortfall in the state budget. Till today the Law No. 19 the Year 2008 on SBSN / Sukuk has risen derivative rules Regulation No. 56 the Year 2011 on Financing the Project through the issuance of Shariah Securities, ${ }^{6}$ This government regulation into the carving knife to finance government projects outlined in the state budget. Similarly, Regulation No. 56 the Year 2008 on the Company Issuing State Sharia, the involvement of the company to accelerate the collection of funds from the public, so that the funds collected are then used to finance government infrastructure such as to finance roads, schools, dormitories Hajj, classrooms, and others.

SBSN issuance is to finance the State Budget (APBN), including financing of the project development (such as infrastructure projects in energy, telecommunications, transportation, agriculture, manufacturing, and housing). ${ }^{7}$ In

5Republic of Indonesia, Law Number 19 Year 2008 concerning the State Sharia Bonds, p. 17

6 Republic of Indonesia, Law No. 1 of 2004 on State Treasury.

7Fence M. Wantu, SH., MH, Introduction to Law, Publisher (Jakarta: Reviva Scholar, 2015), p 25 
line with the main objective, namely SBSN issuance to finance the state budget, SBSN issuance by the Government is needed, among other things: (1) expand the resource base of state budget financing; (2) encourage the growth and development of the Islamic finance market in Indonesia; (3) strengthen and enhance the role of Islamic financial system in the country; (4) creates a good benchmark Islamic financial instruments in the Islamic financial market domestically and internationally; (5) expand and diversify the investor base; (6) develop alternative investment instruments; (7) to finance infrastructure projects; (8) to optimize the utilization of State Property (BMN). ${ }^{8}$

However Similarly, the Act / 19 / of 2008 on SBSN particularly in articles 10 paragraph mentions (1) State Property can be used for issuing SBSN, hereinafter referred State Property referred to as Asset SBSN. (2) Asset SBSN referred to in paragraph (1) may be a. land and / or building; and b. other than land and / or buildings. (3) The type, value, and specification of State Property to be used as SBSN assets referred to in paragraph (2) shall be determined by the Minister. ${ }^{9}$ On the other hand Article 45 of Law No. 1/2004 mentioned paragraph (1) Goods state / regional necessary to implement the tasks of state government / local non-transferable. (2) Transfer of property of the state/region done by sold, exchanged, assigned, or included as a capital by the Government after approval by Parliament / DPRD. ${ }^{10}$

From the above-mentioned conditions, it can be said that Law No. 19/2008 on SBSN is lexed of Law No. 1 of 2004 on State Treasury. And please note that publishing SBSN also necessary to expand the resource base of state budget financing, so they no longer rely on the instruments of State Bonds and loans from abroad. Also, the issuance of state bonds can also encourage the growth and development of Islamic financial markets in Indonesia and to strengthen and enhance the role of Islamic financial system in the country., On the other hand, the sukuk could also be a benchmark for financial instruments sharia both in the Islamic financial market domestically and internationally, expand and diversify the investor base, developing alternative investment instruments, finance the construction of infrastructure projects, as well as optimizing the utilization of Possession, so that the values maslahah reflected in publishing activities SBSN / Sukuk with a benefit of the ummah.

8 Fence M. Wantu, SH., MH, p. 24

9 Fence M. Wantu, SH., MH, p. 25

10 Fence M. Wantu, SH., MH, p. 26 


\section{B. LAW NUMBER 19 OF 2008 CONCERNING THE LEGAL BASIS AS LEX SBSN SPECIALIST LAW NUMBER 1 the YEAR 2004 CONCERNING THE STATE TREASURY:}

The issuance of Law No. 19/2008 on State Sharia Bonds, if not in line with Law No. 1/2004 on the State Treasury it happens in the case of use as a condition of the issuance of the State Asset SBSN / Sukuk. In Legal Studies there are some legal principles. The principle of law is an essential element of the rule of law and fundamental. Wherever possible practical legal establishment oriented to the principles of law. Legal principle into the fundamentals or directions in the formation of positive law. The principle is something on which the thought or argued. According Satjipto Rahardjo (1996: 47), the legal principle is not a rule of law, but no law can be understood without knowing the legal principles contained in it. Therefore, to understand the laws of a nation as well as possible can not only look at the legal regulations alone but have to dig them up to the fundamental principles of law. The legal principle is what gives meaning to the ethical rules of law and the rule of law. According to The Liang Gie (1982: 10), the principle is a general proposition stated in general terms without suggesting specific ways regarding its implementation, which is applied to a series of actions to be exact instructions for the deed. ${ }^{11}$

Bellefroid found common law principle is the basic norms derived from the positive law and the jurisprudence is not ascribed to the rules are more common. The principle of the common law is the deposition of positive law in society. While van Eikema Hommes that legal principles should not be regarded as legal norms are concrete, but it should be seen as a general basis or guidelines for the law. Legal establishment of practical need-oriented principles of the law. In other words, the principle of the law is to the basics of the directions in the formation of positive law. Another opinion of Van Der Velden, who said that "the principle of the law is a particular type of decision that can be used as a benchmark to assess the situation or be used as a guideline to behave. The principle of the law is based on one or more values that determine the situation which is worth to be realized ". According to Scholten "legal principles are the trends suggested by the view of our morality to the law, a general nature with all its limitations as a general disposition that, but you can not be there."12

From what is described above it can be concluded that the principle of the law is not concrete, but is a basic thought that the general and abstract, or the background of regulation concrete contained in and behind every legal system revealed in the

11 Republic of Indonesia, Law No. 1 of 2004 on State Treasury.

12Republic of Indonesia, Law Number 19 Year 2008 concerning State Sharia Bonds 
legislation and the judge's decision a positive law and can be found by searching for traits or characteristics that are common in the concrete regulations. The principle of law has two runways. The first principle of the law is rooted in the reality of society and the second on the values chosen as a guideline by the common life. The unification of the real factors and ideal law is a principle function of law. ${ }^{13}$

According Sudikno Mertokusumo (2010: 13), the legal principle can be divided as follows: 1 ). The principle of common law that the principle of law that relates to all areas of law such as the principle Restitution in integrum, the principle of lex posteriori derogat legi priori, the principle that what the birth appears to be true (valid), for the time being, should be maintained so until terminated by the court, for the sake of certainty legal, nebis in idem principle. 2). The special legal principle is a legal principle that applies in a particular field of law. This particular legal principle to work in narrower fields such as in the areas of civil law, criminal law and so are often an elaboration of the principles of the common law, such as pacta sunt servanda, the presumption of innocence. ${ }^{14}$

Law No. 1/2004 of Article 45 paragraph (1) Goods state / regional necessary to implement the tasks of state government / local non-transferable. (2) Transfer of property of the state/region done by sold, exchanged, assigned, or included as a capital by the Government after approval by Parliament / DPRD. ${ }^{15}$ while in Act / 19 / of 2008 on SBSN particularly in articles 10 paragraph (1) of State can be used as the basis for the issuance of SBSN, hereinafter referred State Property referred to as Asset SBSN. (2) Asset SBSN referred to in paragraph (1) may be a. land and / or building; and $b$. other than land and / or buildings. (3) The type, value, and specification of State Property to be used as SBSN assets referred to in paragraph (2) shall be determined by the Minister. ${ }^{16}$

Both of the above Act has met the criteria for the UU principle lex / 19 of 2008 because this law is more specific nature, while Law No. 4 of 2004 is more general so that both the Act should go hand in hand. This is also reinforced by the Constitutional Court, by decision No. 143 / PUU-VI1I2009 dated May 7, 2010, of Test Material on use of SOA as an underlying asset SBSN as stipulated in Article 10 paragraph (1) and (2) a and b as well as Article 11 (1) of Law 19/2008, decided among other things that the arguments of the applicant stating BMN for issuing SBSN including the public domain is intended for general interest and therefore can not be

13Https://www.djkn.kemenkeu.go.id/berita/baca/1555/Keabsahan-Penggunaan-Barang-MilikNegara-sebagai-Underlying-Asset-SBSN-Diperkuat-dengan-Keputusan-Mahkamah-Konstitusi.html, Uploaded dated Desember 5, 2019

14 Ministry of Finance, Books FAQ SBSN, Second Edition, 2010, p. 31

15 Republic of Indonesia, Law Number 19 Year 2008 concerning State Sharia Bonds

16 Republic of Indonesia, Law No. 1 of 2004 on State Treasury. 
made the object of trade, is not correct because BMN not made the object of trade, but only as an object of dependents in the form of the right to benefit. BMN for issuing SBSN (underlying asset) is not a guarantee (collateral) that are transferable, while transferable only SBSN its course. ${ }^{17}$

\section{LAW NUMBER 19 OF 2008 CONCERNING THE LEGAL BASIS AS LEX SBSN SPECIALIST Law No. 12004 ON TREASURY OF THE MAQASHID AL- SHARI'AH PERSPECTIVE}

In issuing a SBSN product, it is necessary Underlying assets, that is assets that serve as the object or transaction basis in connection with the issuance of Sukuk. This serves as the underlying assets that may be tangible or intangible goods, such as land, buildings, various types of construction projects, as well as other non-physical assets such as services (services). ${ }^{18}$ It is also mentioned Law 19/2008 expressly provided in Article 10 (1) of State can be used as the basis for the issuance of SBSN, hereinafter referred State Property referred to as Asset SBSN. Article 11 (1) Use of State Assets as Assets SBSN as referred to in Article 10 paragraph (2) shall be the Minister by selling or renting Rights Benefits on State Property or any other manner consistent with that used in the framework Akad SBSN issuance. (2) Asset SBSN referred to in paragraph (1) may be hired back by the Minister under a Akad. ${ }^{19}$ Similarly, in Act 1/2004 Article 45 (1) Item state / regional necessary to implement the tasks of state government / local non-transferable. (2) Transfer of property of the state/region done by sold, exchanged, assigned, or included as a capital by the Government after approval by Parliament / DPRD. ${ }^{20}$

Observing the Act above, into an amplifier that Law 19/2008 is lexed of Law No. 1/2004, SBSN or sukuk is "Sharia Securities hereinafter abbreviated SBSN, or can be called Sukuk, are securities state-issued based on Islamic principles, as evidence for the inclusion of the assets SBSN, both in rupiah or foreign currency. "21

17 Republic of Indonesia, Law Number 19 Year 2008 concerning State Sharia Bonds

18 Accounting and Auditing Organization for Islamic Financial Institutions (AAOIFI) No. 17

19 Ika Yunia Fauziah and Abdul Kadir Riyadi, Basic Principles of Islamic Economics Perspective maqashid al-Syar'ah, (Publisher: Prenamedia Group, Cet. First, 2014), p.41

20 Al-Ghazali, Shifa 'al-Ghalil, tahqiq Hamdi Ubaid al-Killing, (Baghdad: Mathba'ah al-Irsyad, 1971), p. 159

21 Al-Syatibi, Al-Muwafaqat fi Ushu al-Shariah, (Beirut: Dar al-Ma'rifah, t.th), p. 322 


\section{SBSN IN MAQASHID AL-SHARI'A PERSPECTIVE}

The term SBSN or Shariah Securities, the term is used in the language of the Act, the term equal to the sukuk. Based on Sharia Standards The Accounting and Auditing Organization for Islamic Financial Institutions (AAOIFI) No. 17 of the Investment Sukuk (Sukuk Investments), Sukuk is defined as a certificate of equal value which is evidence for the undivided ownership of an asset, the right to benefits and services, or on the ownership of a project or specific investment activities.

"Investment Sukuk are certificates of equal value representing undivided shares in ownership of tangible assets, usufruct, and services or (in the ownership of) the assets of particular projects or special investment activity ". ${ }^{22}$

Al-Shariah maqashid Etymologically maqashid al-shari'ah consists of two words, namely maqdsid and Shari'ah. Maqashid is the plural of maqshud which means intentional or purpose. The Shari'ah means path to the water, or bias is said to be the path to the source of life. ${ }^{23}$ As for the terminology, stated by previous scholars, among others:

Al-Imam al-Ghazali, who put forward the notion maqashid al-Shari'ah, "Guard against the purposes and objectives of Shari'ah is a fundamental effort to survive, restraining factors and encourage prosperity damage". ${ }^{24}$ And Al-Imam al-Syatibi provide understanding, "Al-maqashid divided into two: the first, about the purpose of God as the giver as shari'ah; and secondly, about the intent mukallaf. ${ }^{25}$

Back to the intent Syari '(Allah) is the benefit to His slaves in two places; the world and the hereafter. And return to the intent muqallaf (human) is when His servants are encouraged to live in welfare in this world and hereafter. By avoiding the defects that exist in the world. Therefore, there must be an explanation of benefit (maslahah) and damage (mafsadah). ${ }^{26} \mathrm{Ahmad}$ al-Rasysuni, provide understanding maqashid al-Shari'ah, "maqashid al-Shari'ah are the objectives set by the Shari'ah to be achieved for human kemsalahatan". ${ }^{27}$ Similarly, the notion expressed by Abdul Wahab

102

22 A'thiyaah Jamal al-Din, Al-Nadzariyah al-ammah li-al-Shariah al-Islamiyah, (nd, 1988), p.

23 Ahmad al-Raysuni, Nadzariyah al-maqashid Inda al-Imam al-Syatibi, (Beirut: al-Ma'had li al-Ali al-Fikr al-Islami, al-Muassasah al-Jamiiyah li al-Dirasat wa al-Nasr wa al-Tawzi, t, th.) h. 45

24 Abdul Wahhab Khallaf, Science Usul Fiqhi, (Kuwait: Dar al-Qalam li a; -Nashr wa alTawzi, 1990), p. 197

25 Ika Yunia Fauziah and Abdul Kadir Riyadi, Basic Principles of Islamic Economics Perspective maqashid al-Syar'ah,,Basic Principles of Islamic Economics Perspective maqashid alSyar'ah, P. 43

26 Al-Syatibi, Al-Muwafaqat fi al-Shariah Ushu, P. 374

27 Ministry of Finance, Books FAQ SBSN, Second Edition, 2010, p. 30-31 
Khallaf, namely " The general objective when God determines the law-the law is to realize human welfare with the needs of the dharuriyah, hajiyyah, and tahsiniyah". ${ }^{28}$

From some of the above, it can be said that the "maqasid al-Shari'ah" is the purpose of God as the creator of sharia to provide benefit to humans. Namely fulfillment dharuriyah, hajiyah, and tahziniyah so that people can live in goodness and can be a good servant of God. ${ }^{29}$

According to al-Syatibi, the human benefit can be realized if the five basic elements of human life can be achieved and maintained, the religion, life, intellect, lineage, and property. Within this framework, Syatibi maqashid divide into three levels, namely dharuriyat, hajiyat, and tahziniyah. ${ }^{30}$ Maqasid al-Shari'ah, if associated with SBSN, then publishing SBSN consists of two-dimensional, the first dimension: SBSN as an investment, and a second dimension SBSN, as a financing instrument.

\section{E. SBSN AS SHARIAH BONDS INVESTMENT PRODUCTS}

Currently in Indonesia have the awareness to invest had started to become a culture for the majority of our society. This investment is important because it is part of the financial planning for the times to come. Muslims especially those who no guidance to prepare future needs with the preparation of funding from now on. One way to invest it. Many investment products that could be an option, but one thing to note is that the investment must be by the guidelines syar'i. Whether we realize it or not, every financial transaction, for example, any investment, it is not uncommon to contain things contrary to the basic principles of Islamic Shariah. This is why many banking institutions also recently issued investment products Sharia-based as alternatives to the products of conventional banking institutions.

The Government of Indonesia through the Ministry of Finance has launched several products sukuk, as investment products to both individuals and institutions. As there are seven types of Shariah bonds sukuk for each type of investor: 1 . institutional investors in the domestic market, including: (a). IFR (Islamic Fixed Rate) to the first issue in August 2008 to 2012, (b) SPN-S (Treasury Bills Shari'ah), (c) SDHI (Sukuk Fund Haji Indonesia), (d) PBS (Project Based Sukuk), (e) SR (Sukuk ritel), (f) ST (savings bonds, (g) SNI (Indonesian state sukuk). type Sukuk requires the underlying assets: BMN \& Projects, for sukuk assets, are SDHI underling Haj services. ${ }^{31}$ The advantage of investment in sukuk, is, in the form of a reward, and this reward is not of interest (interest), but arising from transactions on underlying assets

28 Ministry of Finance, Books FAQ SBSN, Second Edition, 2010, p. 17

29 Ministry of Finance, Books FAQ SBSN, Second Edition, 2010, p. 17

30 GOI, Government Regulation No. 56 Year 2011, Through Project Financing Issuance of Securities Shariah State

31 Abdul Wahhab Khallaf, Science Usul Fiqhi, p. 197 
SBSN. It is therefore not investing in sukuk bonds but in the form of a certificate on proof of ownership of certain assets or investments, investment securities also based on real transactions of tangible and intangible assets used-contract agreement Shari'ah, therefore sukuk according to the principles of Shariah, so there should be no element of gambling (masysir), uncertainty (gharar), and interest (riba).

\section{F. SBSN AS FINANCING PRODUCTS}

With the main objective, namely SBSN issuance to finance the state budget, SBSN issuance by the Government is needed, among other things: (a) expand the resource base of state budget financing; (B) encourage the growth and development of Islamic financial markets in Indonesia (c) strengthen and enhance the role of Islamic financial system in the country; (D) creates a good benchmark Islamic financial instruments in the Islamic financial market domestically and internationally; (E) expand and diversify the investor base; (F) developing alternative investment instruments; $(G)$ to finance infrastructure projects; $((\mathrm{H})$ to optimize the utilization of State Property (BMN). ${ }^{32}$

One SBSN is financing for infrastructure projects, as stipulated in Government Regulation No. 56 the Year 2011 Article 9, that the scope of the project (a). infrastructure development includes the energy sector, telecomunication, transport, agriculture, industrial manufacturing; (B) the provision of public services; (C) empowerment of the domestic industry; (D) any other appropriate development of strategic government. Besides, several requirements must be met to use SBSN to finance the project, especially in article 10 in Regulation No. 56 of 2011, namely that the project will be built is not contrary to Islamic principles, and chapters 24-26 that will not be transferred or eliminated over into asset SBSN. ${ }^{33}$

See SBSN above objectives, which could become an Islamic bond investment, on the other hand as well as financing, if viewed from the maqasid al-Shari'ah, then SBSN can be said to achieve the benefit. A better understanding could be described as SBSN for the maslahah table below.

32 Ministry of Finance, Books FAQ SBSN, Second Edition, 2010, p. 17

33 GOI, Government Regulation No. 56 Year 2011, Through Project Financing Issuance of Securities Shariah State 


\begin{tabular}{|c|c|c|}
\hline Aim & Commentary & Maqashid as-Syaria'h \\
\hline $\begin{array}{l}\text { Law No. 19/2008 } \\
\text { on the State } \\
\text { Shariah Securities: } \\
\text { to finance the } \\
\text { state's finances } \\
\text { and the } \\
\text { construction of } \\
\text { government } \\
\text { projects }\end{array}$ & $\begin{array}{l}\text { - UU no. Being lex 19/2008 of Law No. } \\
1 \text { of } 2004 \text { on State Treasury in the } \\
\text { utilization of state assets } \\
\text { - SBSN, must comply with the } \\
\text { principles of Shari'ah in aqad and } \\
\text { use, and does not contain gharar, } \\
\text { maysir, riba (interest) } \\
\text { - SBSN to build the infrastructure of } \\
\text { education infrastructure, in the form } \\
\text { of the lecture hall, the school } \\
\text { building, laboratories, public facilities } \\
\text { such as roads, hospitals and others. }\end{array}$ & $\begin{array}{l}\text { Maintain Intellect, } \\
\text { Soul, Honor }\end{array}$ \\
\hline
\end{tabular}

\section{G. CONCLUSION}

Law Number 19 Year 2008 concerning the State Shariah Bonds is lex Act No. 1 of 2004 on State Treasury in the utilization of state assets. SBSN product has two dimensions, namely as Islamic bonds and investment products as the country's financial financing products and projects of common interest of the government, such as roads, buildings and other education. SBSN contains maslahah therein, because this SBSN in order to keep religion, soul, mind, wealth and honor. 


\section{BIBLIOGRAPHY}

Accounting and Auditing Organization for Islamic Financial Institutions (AAOIFI) No. 17

Al-Ghazali, Shifa 'al-Ghalil, tahqiq Hamdi Ubaid al-Killing, (Baghdad: Mathba'ah alIrsyad, 1971)

Al-Raysuni Ahmad, al-maqashid Nadzariyah Inda al-Imam al-Syatibi, (Beirut: alMa'had li al-Ali al-Fikr al-Islami, al-Muassasah al-Jamiiyah li al-Dirasat wa alNasr wa al-Tawzi, $t$, th.)

Al-Syatibi, Al-Muwafaqat fi Ushu al-Shariah, (Beirut: Dar al-Ma'rifah, t.th)

A'thiyaah Jamal Al-Din Al-Nadzariyah al-ammah li-al-Shariah al-Islamiyah, (nd, 1988)

Fauziah Ika Junia, Lc., MEI and Dr. Abdul Kadir Riyadi, Lc., MSC, Basic Principles of Islamic Economics Perspective maqashid al-Syar'ah, (Publisher: Prenamedia Group, Cet. First, 2014),

https://www.djkn.kemenkeu.go.id/berita/baca/1555/Keabsahan-Penggunaan-BarangMilik-Negara-sebagai-Underlying-Asset-SBSN-Diperkuat-dengan-KeputusanMahkamah-Konstitusi.html, Uploaded dated July 5, 2019

Khallaf Abdul Wahhab, Science Usul Fiqhi, (Kuwait: Dar al-Qalam li a; -Nashr wa alTawzi, 1990)

M.Wantu Fence, Introduction to Law, Publisher: (Reviva Scholar), 2015

Ministry of Finance, Tanya Books Shariah Securities, second edition 2010

Republic of Indonesia, Government Regulation No. 56 of 2008, concerning the Project Financing Through State Shariah Securities Issuance

Republic of Indonesia, Law No. 1 of 2004 on State Treasury.

Republic of Indonesia, Law Number 19 Year 2008 concerning State Sharia Bonds 